\title{
Pembelajaran Daring di Masa Pandemi Covid-19 pada Perguruan Tinggi Keagamaan Islam Negeri (Studi di IAIN Pekalongan)
}

\author{
Fatmawati Nur Hasanah $^{1 *}$, Toni Setiawan ${ }^{2}$ \\ 1. Program Studi Pendidikan Agama Islam, IAIN Pekalongan. \\ 2. Program Studi Pendidikan Vokasional Teknik Mesin, Universitas Ivet. \\ *1.e-mail: fatmawati.nur.hasanah@iainpekalongan.ac.id \\ 2.tonisetiawan@ivet.ac.id
}

\begin{abstract}
Abstrak
Penelitian ini menggunakan pendekatan kuantitatif dengan metode survei yang bertujuan untuk memperoleh gambaran pembelajaran daring yang dilaksanakan di IAIN Pekalongan sebagai usaha untuk menekan penyebaran Covid-19 di lingkungan kampus. Pembelajaran daring yang dimaksud dalam penelitian ini adalah pembelajaran yang menggunakan media-media pembelajaran yang dapat diakeses menggunakan layanan internet. Survei dilaksanakan menggunakan google form yang tautannya disebarkan melalui afplikasi WhatsApp. Mahasiswa sebagai sampel yang memberikan tanggapan terhadap survei yang dilakukan terdiri dari Prodi Pendidikan Agama Islam, Prodi Pendidikan Islam Anak Usia Dini, Prodi Ekonomi Syariah, Prodi Hukum Keluarga Islam, dan Prodi Tasawuf Psikoterapi.

Media elearning yang digunakan oleh mahasiswa IAIN Pekalongan selama pandemi Covid-19 adalah google classroom, e-learning milik kampus, dan whatsapp. Untuk perkulihan tatap muka secara daring menggunakan zoom dan google meet. Durasi penggunaan waktu untuk pembelajaran daring selama pandemi Covid-19 antara 5$6 \mathrm{jam} /$ hari atau setara dengan tatap muka konvensional, ini dapat diartikan bahwa dosen-dosen IAIN Pekalongan melakukan tugas sebagaimana mestinya meskipun dari rumah (work from home). Adapun penyedia jasa internet yang digunakan adalah Indosat, XL, Three, dan Smartfren dengan kuota data internet yang dihabiskan antara 6-10 GB/bulan dan 16-20 GB/bulan.
\end{abstract}

Kata Kunci: Pembelajaran Daring, Pandemi, Covid-19.

\begin{abstract}
This study uses a quantitative approach with a survei method that aims to obtain an overview of online learning carried out at IAIN Pekalongan as an effort to enforce the spread of Covid-19 in the campus environment. Online learning referred to in this study is learning that uses learning media that can be used using the internet. The survei was carried out using a google form, the link of which was distributed via the WhatsApp application. These samples students consisted of the Islamic Education Study Program, the Early Childhood Islamic Education Study Program, the Sharia Economics Study Program, the Islamic Family Law Study Program, and the Psychotherapy Sufism Study Program.

The e-learning media used by IAIN Pekalongan students during the Covid-19 pandemic were google classrooms, campus-owned e-learning, and WhatsApp. For face-to-face online courses using zoom and google meet. The duration of using time for online learning during the Covid-19 pandemic is between 5-6 hours / day or equivalent to conventional face-to-face, this means that IAIN Pekalonga lecturers are doing assignments even from home (working from home). The internet service providers used are Indosat, XL, Three, and Smartfren with internet data quota that is consumed between 6-10 GB / month and 16-20 GB / month.
\end{abstract}

Keywords: Online Learning, Pandemic, Covid-19. 


\section{PENDAHULUAN}

Semenjak Covid-19 melanda di Indonesia tidak bisa dipungkiri bahwa segala aspek terkena dampaknya, mulai dari ekonomi sampai ke ranah pendidikan. Covid-19 berdampak signifikan pada proses kegiatan belajar mengajar, tidak mengherankan karena berbagai larangan bepergian dan pembatasan sosial (social distancing), pun juga terjadi pada kehadiran peserta didik/mahasiswa dalam sekolah karena penutupan sekolah dan kampus sebagai misal di Indonesia bahkan juga terjadi di beberapa negara maju antara lain Australia dan Inggris (Goulas \& Megalokonomou, 2020), mengakibatkan kurangnya intensitas pertemuan antara dosen dengan mahasiswa dan menuntut penggunaan teknologi pendidikan terkini yang bersifat adaptive (Setiawan et al., 2019). Saat kita semua belajar dan bekerja dari jauh, melakukan pertemuan secara elektronik melalui aplikasi teleconference seperti zoom dan Microsoft Teams (Almarzooq et al., 2020), Virtual Reality (Singh et al., 2020) (Almarzooq et al., 2020), maka kemampuan untuk menggunakan teknologi informasi (TI) dituntut meningkat.

Sejak dideklarasikannya Covid-19 sebagai pandemi oleh WHO pada 11 Maret 2020 (Kapasia et al., 2020) dan kebijakan pemerintah melalui Surat Edaran Direktur Jenderal Pendidikan Tinggi Republik Indonesia Nomor 1 Tahun 2020 (Nizam, 2020) \& Surat Edaran Nomor 3 Tahun 2020 Tentang Pencegahan Corona Virus Disase (Covid-9) Pada Satuan Pendidikan (Makarim, n.d.) banyak warga tidak terkecuali mahasiswa merasa cemas dan ketakutan akan infeksi virus tersebut sehingga menimbulkan gangguan kejiwaan antara lain post-traumatic stress, gangguan depresi dan kecemasan, serta gejala yang berhubungan dengan kesedihan (Guessoum et al., 2020) dan menjadi perhatian oleh psikiater sehingga lahirlah sebuah Conceptual Framework untuk penangan masalah mental (Ransing et al., 2020).

Pelajar dan pendidik perlu mendapat edukasi tentang Covid-19. Edukasi tentang Covid-19 sendiri sudah dilakukan baik secara nasional maupun internasional, secara nasional pemerintah Indonesia melalui situs resmi https://covid19.go.id/ dan Organisasi Kesehatan Dunia (WHO) melalui kursus dengan empat modul meliputi sifat virus pernapasan yang muncul, cara mendeteksi dan menilai wabah, strategi untuk mencegah dan mengendalikan wabah karena virus pernapasan baru, strategi apa yang harus digunakan mengkomunikasikan risiko dan melibatkan komunitas untuk mendeteksi, mencegah munculnya virus pernapasan baru. Setiap modul juga menyediakan sumber informasi tambahan dan lamanya studi kurang lebih 3 jam dan tersedia dalam dua belas bahasa lain selain bahasa Inggris. Lihat https://www.futurelearn.com/courses/covid19-novel-coronavirus (Chiodini, 2020).

WHO merekomendasikan penghentian sementara kegiatan-kegiatan yang berpotensi menimbulkan kerumunan massa sebagai usaha pencegahan penyebaran Covid-19, salah satu diantaranya adalah pembelajaran konvensional yang mengumpulkan banyak mahasiswa dalam satu ruangan perlu ditinjau ulang pelaksanaannya. Pembelajaran harus dilaksanakan dengan skenario yang mampu meminimalisir kontak fisik antara mahasiswa dengan mahasiswa lain, ataupun antara mahasiswa dengan dosen (Firman \& Rahayu, 2020).

Penutupan sekolah dan kampus menjadi langkah mitigasi paling efektif untuk meminimalisir penyebaran wabah pada siswa dan mahasiswa. Kebijakan social distancing maupun physical distancing guna meminimalisir penyebaran Covid-19 mendorong semua elemen pendidikan untuk mengaktifkan kelas meskipun sekolah tutup, solusi yang 
diberikan yakni dengan memberlakukan pembelajaran dirumah dengan memanfaatkan berbagai fasilitas penunjang yang mendukung (Herliandry et al., 2020).

Tsunami pembelajaran online telah terjadi hampir diseluruh dunia selama pandemi Covid19 dan krisis kesehatan yang diakibatkan oleh wabah Covid-19 telah mempelopori pembelajaran online secara serempak (Goldschmidt, 2020), lebih lanjut (Goldschmidt, 2020) mengungkapkan meskipun beberapa pengajar merasa enggan dengan peralihan ruang kelas menjadi kelas online. Berbagai aplikasi digunakan untuk mendukung pembelajaran daring antara lain Google Classroom, Whatsapp, Quipper, Microsoft, dan lain-lain (Herliandry et al., 2020), meskipun secara kerucut pengalaman Edgar Dale media online berperan hanya 30\% (Smaldino et al., 2004). Adapun metode pembelajaran yang digunakan mulai dari penugasan hingga problem based learning (Marshall et al., 2008).

\section{Metode}

Penelitian ini menggunakan pendekatan kuantitatif dengan metode survei yang bertujuan untuk memperoleh gambaran pembelajaran daring yang dilaksanakan di IAIN Pekalongan sebagai usaha untuk menekan penyebaran Covid-19 di lingkungan kampus. Pembelajaran daring yang dimaksud dalam penelitian ini adalah pembelajaran yang menggunakan mediamedia pembelajaran yang dapat diakeses menggunakan layanan internet. Survei dilaksanakan menggunakan google form yang tautannya disebarkan melalui applikasi WhatsApp. Mahasiswa sebagai sampel yang memberikan tanggapan terhadap survei yang dilakukan terdiri dari Prodi Pendidikan Agama Islam, Prodi Pendidikan Islam Anak Usia Dini, Prodi Ekonomi Syariah, Prodi Hukum Keluarga Islam, dan Prodi Tasawuf Psikoterapi.

Aspek-aspek yang ditanyakan dalam survei antara lain : 1) Percaya atau tidaknya mahasiswa akan Covid-19; 2) Sejak kapan mahasiswa mengetahui bahwa Covid-19 ada di Indonesia; 3) Darimanakah mahasiswa mengetahui perkembangan kasus Covid-19; 4) Media elearning apakah yang digunakan selama pandemi Covid-19; 5) Aplikasi video conference apakah yang digunakan untuk pembelajaran daring selama pandemi Covid-19; 6) Durasi penggunaan internet untuk pembelajaran daring selama pandemi Covid-19; 7) Operator penyedia jasa internet yang digunakan dalam pembelajaran daring selama pandemi Covid-19; 8) Penggunaan data internet dalam pembelajaran daring selama pandemi Covid-19; 9) Biaya yang dikeluarkan untuk membeli data internet guna pembelajaran daring (termasuk mengerjakan tugas-tugas) selama pandemi Covid-19; 10) Perasaan mahasiswa ketika pembelajaran daring selama pandemi Covid-19; 11) Keinginan mahasiswa dalam menggunakan pembelajaran daring ketika pandemi Covid-19 sudah berakhir; 12) Saat menjalani new normal (era normal baru), bagaimanakah proporsi pembelajaran di kampus yang mahasiswa inginkan.

Analisis data penelitian ini dapat dilakukan menggunakan metode statistik deskriptif (Rinehart, 2012) guna menggambarkan hasil survei untuk menarik kesimpulan. 


\section{Hasil}

1. Percaya atau tidaknya mahasiswa akan Covid-19.

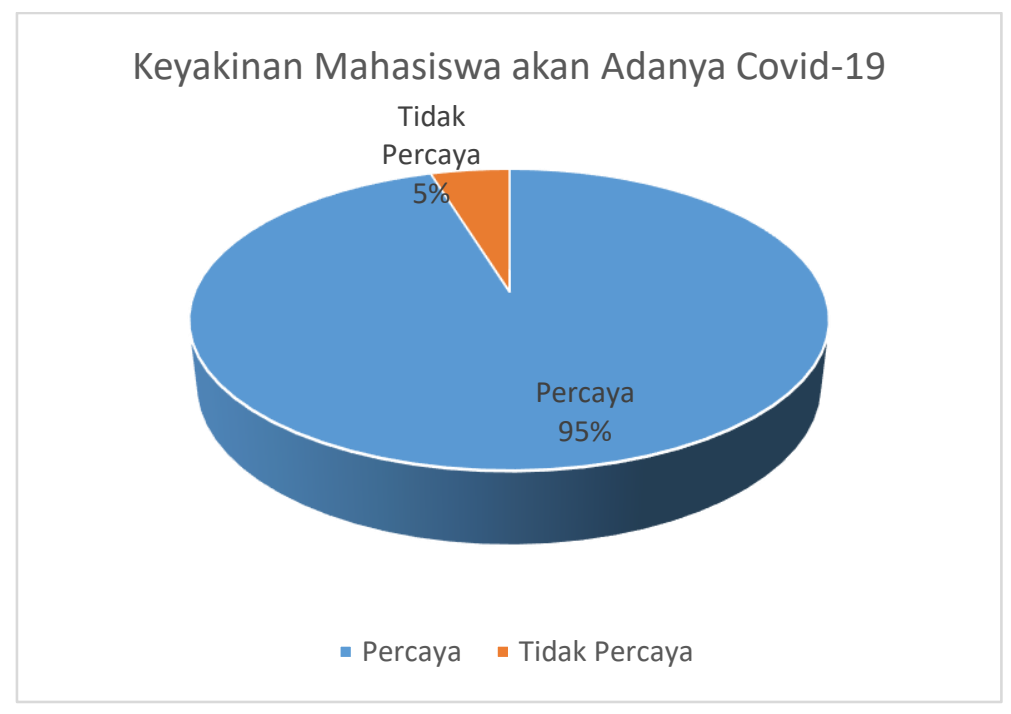

Berdasarkan jawaban responden pada pertanyaan "percaya atau tidaknya mahasiswa akan Covid-19" dapat diketahui bahwa 95\% responden menyatakan percaya akan adanya Covid-19 dan 5\% responden tidak percaya.

2. Sejak kapan mahasiswa mengetahui bahwa Covid-19 ada di Indonesia.

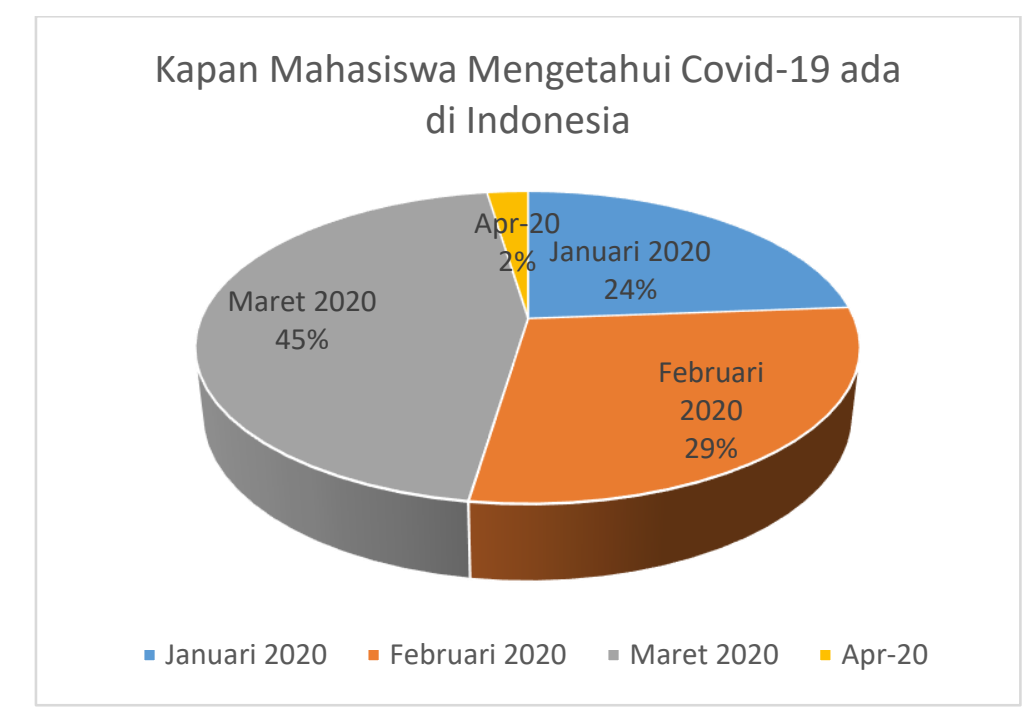

Berdasarkan jawaban responden pada pertanyaan "sejak kapan mahasiswa mengetahui bahwa Covid-19 ada di Indonesia" dapat diketahui bahwa 24\% responden menjawab Januari 2020, 29\% responden menjawab Februari 2020, 45\% responden menjawab Maret 2020, dan 2\% responden menjawab pada April 2020. 
3. Darimanakah mahasiswa mengetahui perkembangan kasus Covid-19.

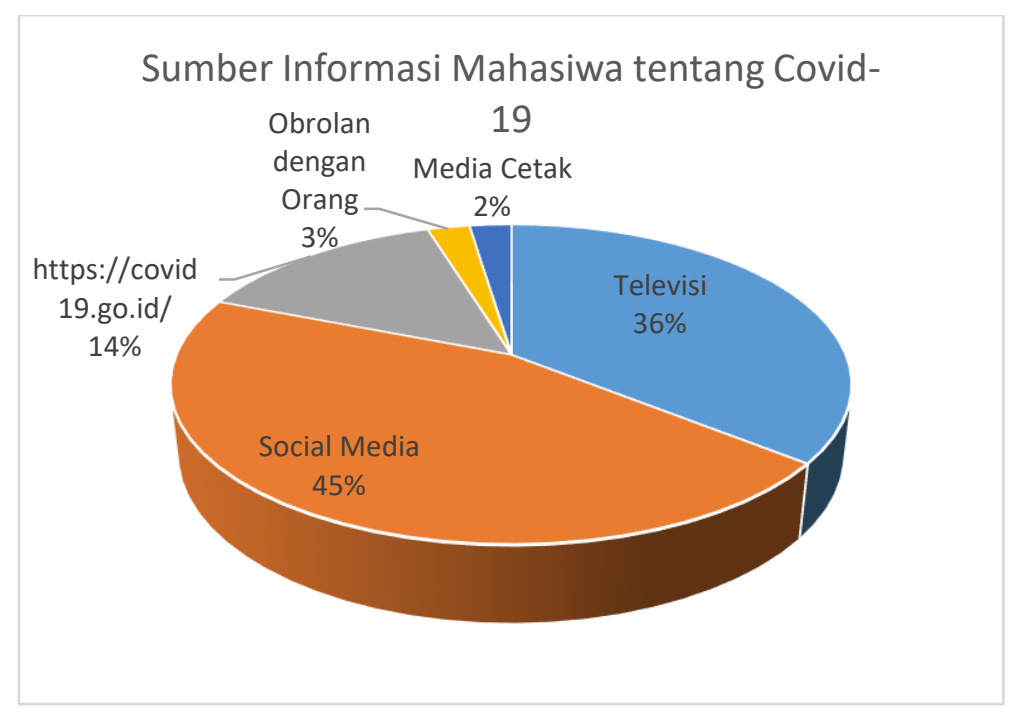

Berdasarkan jawaban responden pada pertanyaan "darimanakah mahasiswa mengetahui perkembangan kasus Covid-19" dapat diketahui bahwa $45 \%$ responden menjawab pada social media, 36\% responden dari televisi, $14 \%$ responden dari situs pemerintah https://covid19.go.id/, 3\% responden menjawab obrolan dengan orang, dan $2 \%$ responden menjawab pada media cetak.

4. Media elearning apakah yang digunakan selama pandemi Covid-19.

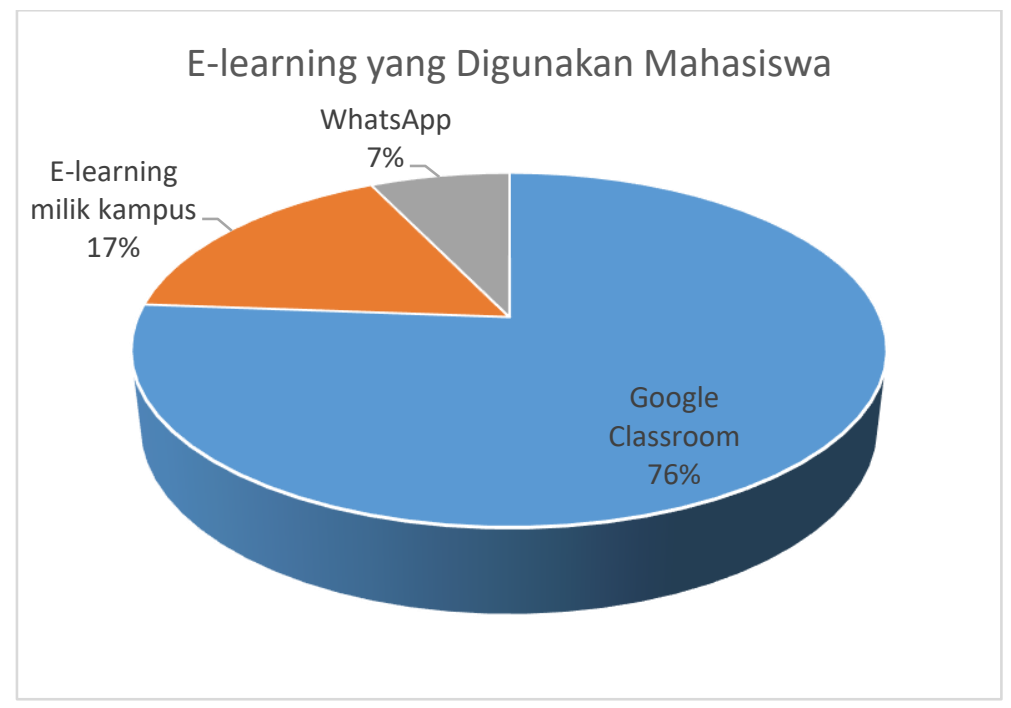

Berdasarkan jawaban responden pada pertanyaan "media elearning apakah yang digunakan selama pandemi Covid-19" dapat dikeathui bahwa 76\% responden menjawab google classroom, $17 \%$ responden menajawab e-learning milik kampus, dan $7 \%$ responden menajawab whatsapp. 
5. Aplikasi video conference apakah yang digunakan untuk pembelajaran daring selama pandemi Covid-19.

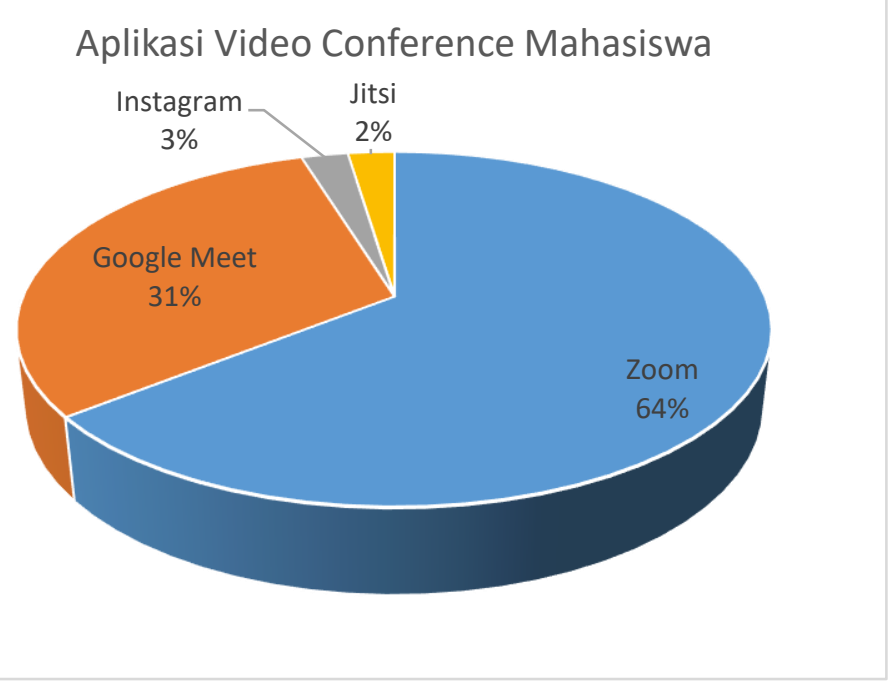

Berdasarkan jawaban responden pada pertanyaan "aplikasi video conference apakah yang digunakan untuk pembelajaran daring selama pandemi Covid-19" dapat diketahui bahwa $64 \%$ responden menjawab zoom, 31\% responden menjawab google meet, $3 \%$ responden menjawab instagram, dan $2 \%$ responden menjawab jitsi.

6. Durasi penggunaan internet untuk pembelajaran daring selama pandemi Covid-19.

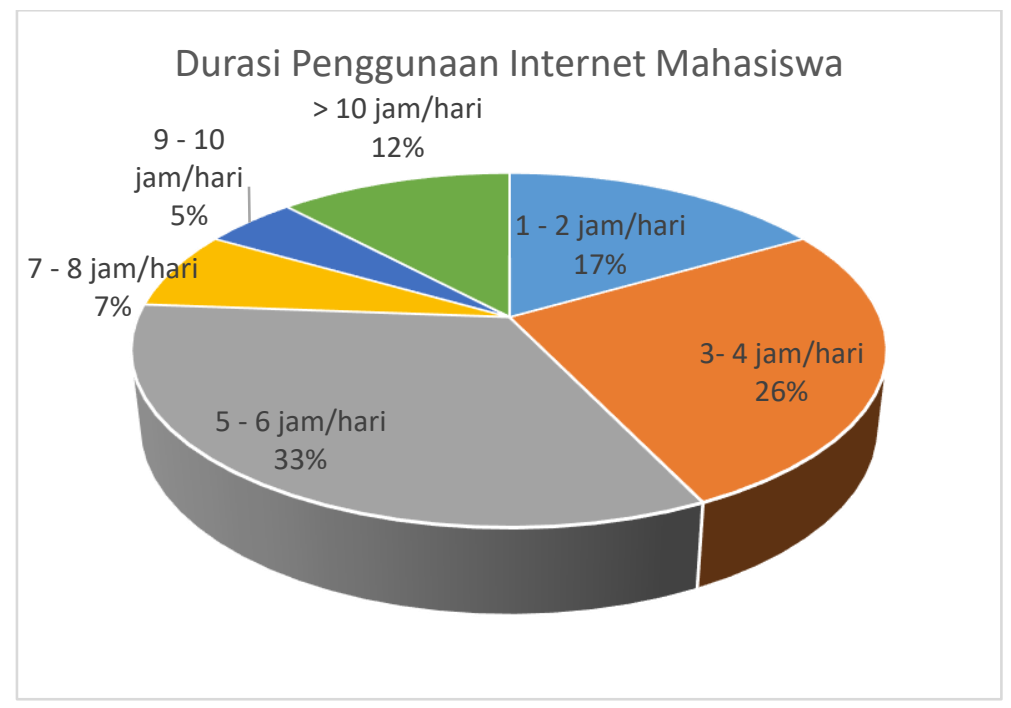

Berdasarkan jawaban responden pada pertanyaan "durasi penggunaan internet untuk pembelajaran daring selama pandemi Covid-19" dapat dikeathui bahwa 33\% responden menjawab 5-6 jam/hari, 26\% responden menjawab 3-4 jam/hari, $17 \%$ responden menjawab 1-2 jam/hari, $12 \%$ responden menjawab > 10 jam/hari, $7 \%$ responden menjawab 7-8 jam/hari, dan 5\% responden menjawab 9-10 jam/hari. 
7. Operator penyedia jasa internet yang digunakan dalam pembelajaran daring selama pandemi Covid-19.

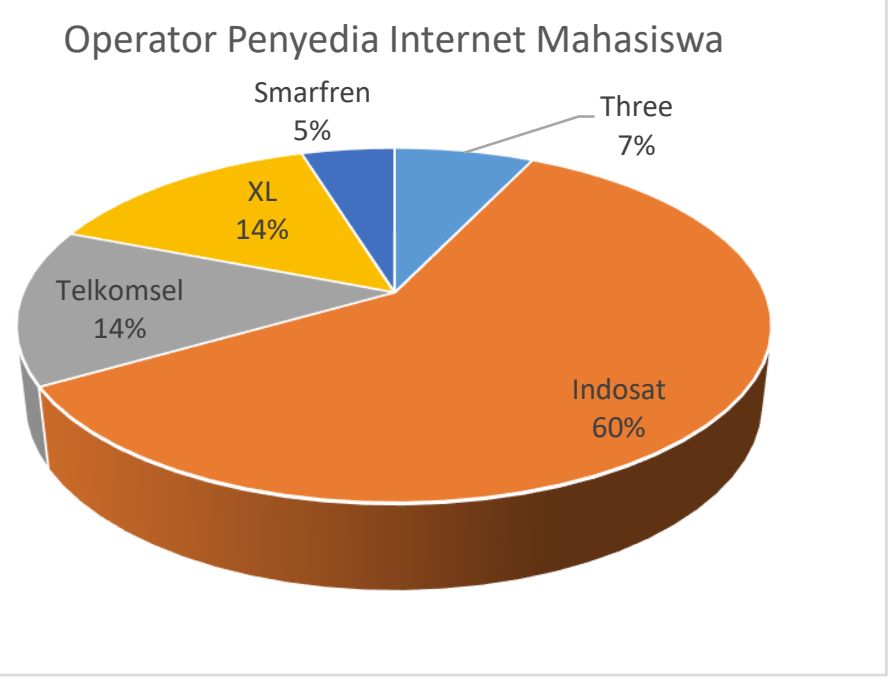

Berdasarkan jawaban responden pada pertanyaan "operator penyedia jasa internet yang digunakan dalam pembelajaran daring selama pandemi Covid-19" dapat diketahui bahwa $60 \%$ responden menajwab Indosat, 14\% responden menjawab Telkomsel, 14\% responden menjawab XL, 7\% responden menajwab Three, dan 5\% responden menjawab Smartfren.

8. Penggunaan data internet dalam pembelajaran daring selama pandemi Covid-19.

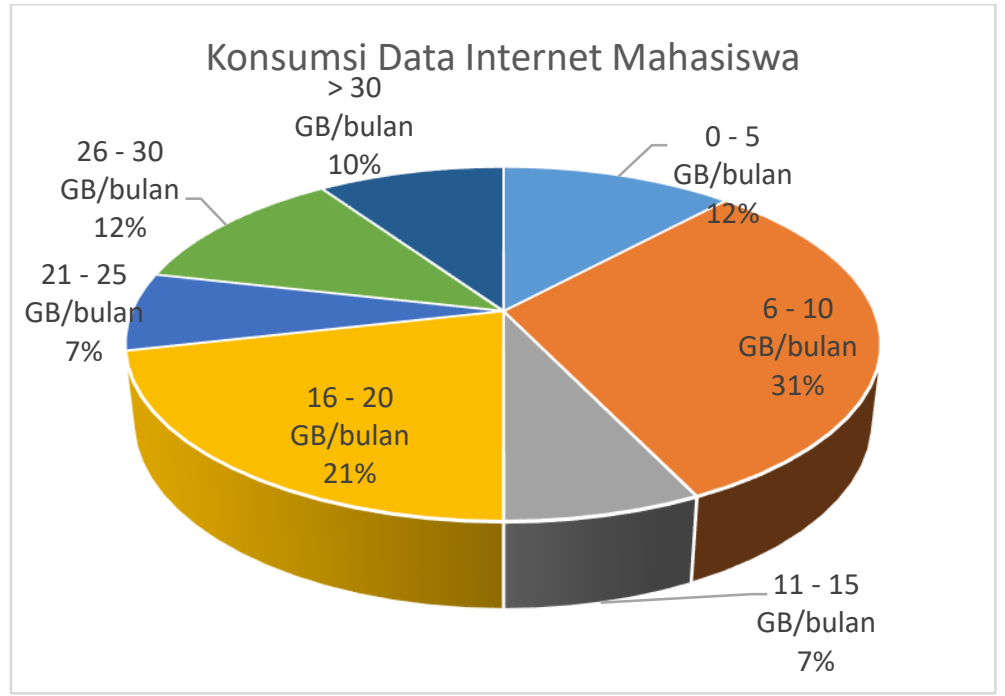

Berdasarkan jawaban responden pada pertanyaan "penggunaan data internet dalam pembelajaran daring selama pandemi Covid-19" dapat diketahui bahwa $31 \%$ responden menjawab 6-10 GB/bulan, $21 \%$ responden menjawab 16-20 GB/bulan, $12 \%$ responden menjawab 0-5 GB/bulan, $12 \%$ responden menjawab 26-30 GB/bulan, $10 \%$ responden menjawab >30 GB/bulan, dan $7 \%$ responden menjawab 21-25 GB/bulan. 
9. Biaya yang dikeluarkan untuk membeli data internet guna pembelajaran daring (termasuk mengerjakan tugas-tugas) selama pandemi Covid-19.

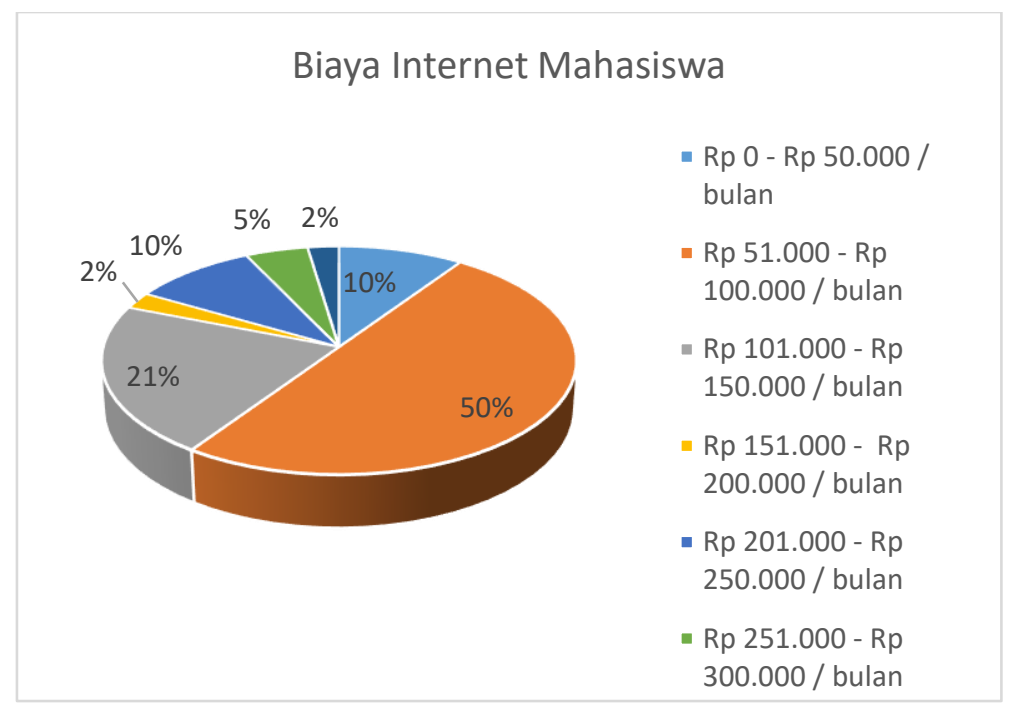

Berdasarkan jawaban responden pada pertanyaan "biaya yang dikeluarkan untuk membeli data internet guna pembelajaran daring (termasuk mengerjakan tugas-tugas) selama pandemi Covid-19" dapat diketahui bahwa 50\% responden menajawab Rp 51.000 - Rp 100.000/bulan, 21\% responden menajawab Rp 101.000 - Rp 150.000/bulan, 10\% responden menajawab $\mathrm{Rp} 0$ - Rp 50.000/bulan, 10\% responden menajawab Rp 201.000 $\mathrm{Rp} 250.000 /$ bulan, 5\% responden menajawab Rp 251.000 - Rp 300.000/bulan, dan 2\% responden menajawab Rp 151.000 - Rp 200.000/bulan.

10. Perasaan mahasiswa ketika pembelajaran daring selama pandemi Covid-19.

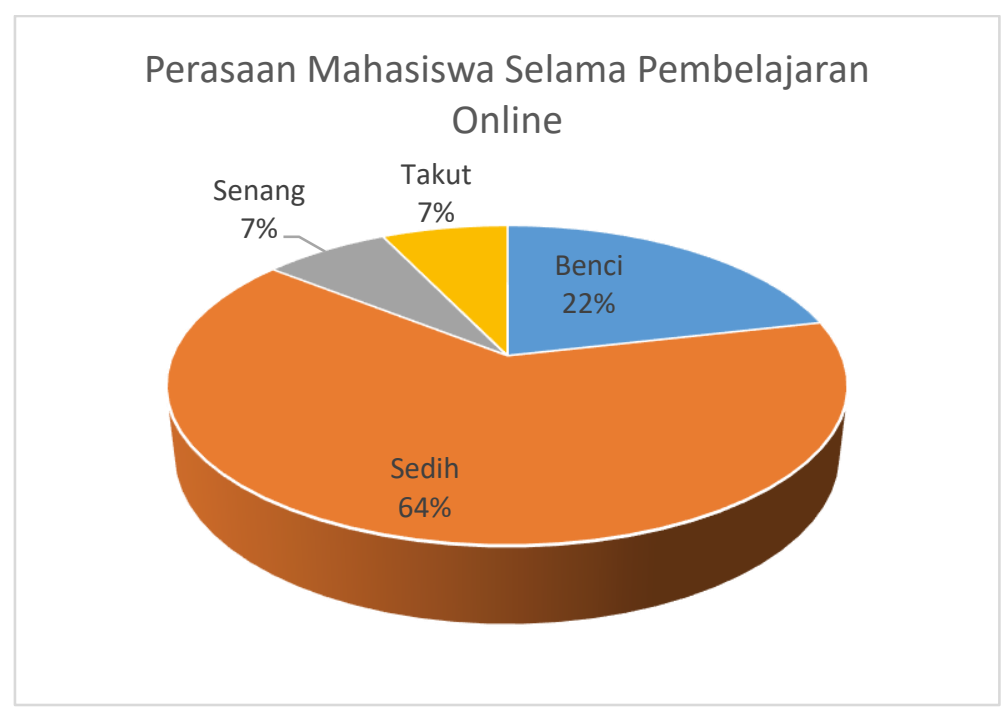

Berdasarkan jawaban responden pada pertanyaan "perasaan mahasiswa ketika pembelajaran daring selama pandemi Covid-19" dapat dikeathui bahwa 64\% responden menjawab sedih, $22 \%$ responden menjawab benci, $7 \%$ responden menjawab takut, dan $7 \%$ responden menajawab senang. 
11. Keinginan mahasiswa dalam menggunakan pembelajaran daring ketika pandemi Covid-19 sudah berakhir.

\section{Keinginan Mahasiswa untuk Pembelajaran \\ Secara Online ketika Pandemi Berakhir}

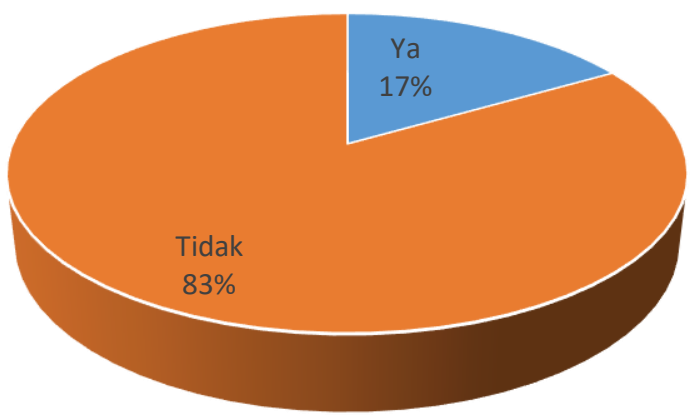

Berdasarkan jawaban responden pada pertanyaan "keinginan mahasiswa dalam menggunakan pembelajaran daring ketika pandemi Covid-19 sudah berakhir" dapat diketahui bahwa $83 \%$ responden menjawab tidak dan $17 \%$ responden menjawab ya.

12. Saat menjalani new normal (era normal baru), bagaimanakah proporsi pembelajaran di kampus yang mahasiswa inginkan.

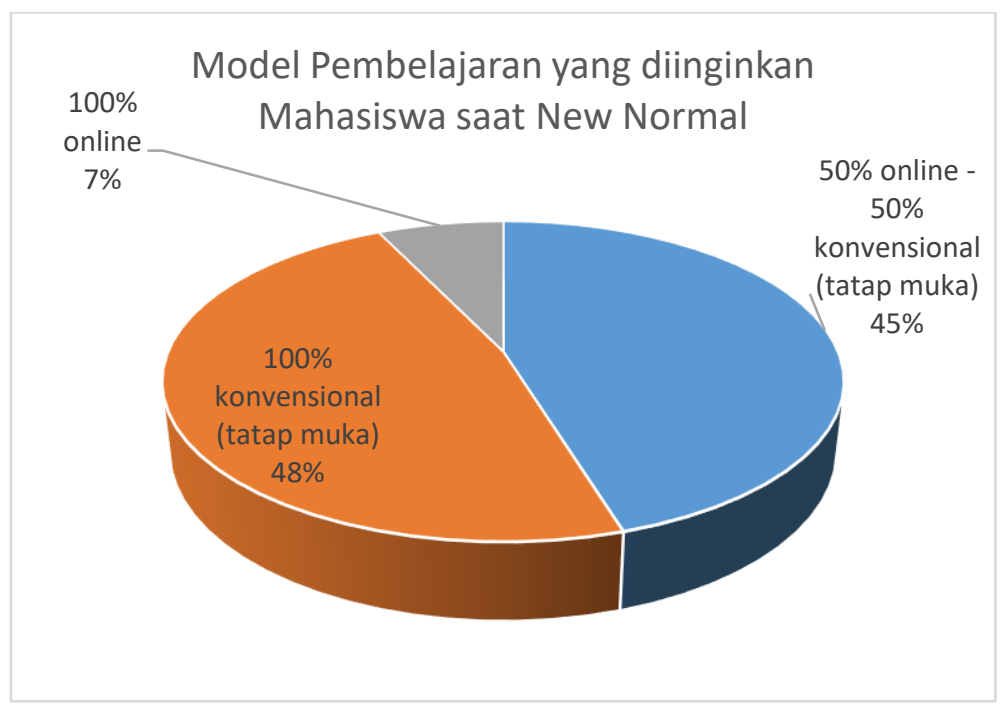

Berdasarkan jawaban responden pada pertanyaan "saat menjalani new normal (era normal baru), bagaimanakah proporsi pembelajaran di kampus yang mahasiswa inginkan" dapat diketahui bahwa 48\% responden menjawab 100\% konvensional (tatap muka), 45\% responden menjawab 50\% online $-50 \%$ konvensional (tatap muka), dan $7 \%$ responden menjawab $100 \%$ online. 


\section{Pembahasan}

Meskipun rumor yang beredar di masyarakat bahwa sebagian orang tidak percaya dengan adanya Covid-19 akan tetapi justru mahasiswa IAIN Pekalongan hampir keseluruhan percaya bahwa Covid-19 itu ada, dan sebagian besar mereka mengetahui Covid-19 masuk di Indonesia sejak Maret 2020. Mahasiswa IAIN Pekalongan mengetahui perkembangan kasus Covid-19 sebagian besar melalui media sosial.

Media e-learning yang digunakan selama pandemi Covid-19 oleh mahasiswa IAIN Pekalongan sebagian besar adalah google classroom, untuk perkuliahan tatap muka secara online sebagian besar menggunakan aplikasi video conference Zoom dan Google Meet. Mahasiswa IAIN Pekalongan sebagian besar menggunakan waktu 5-6 jam/hari untuk pembelajaran daring selama pandemi Covid-19 dengan menggunakan penyedia jasa internet yaitu $60 \%$ Indosat, 14\% Telkomsel, 14\% XL, 7\% Three, dan 5\% Smartfren. Adapun kuota data internet yang dihabiskan sebagian besar adalah 6-10 GB/bulan dan 16-20 GB/bulan dengan mengeluarkan biaya antara Rp 51.000 - Rp 100.000/bulan dan Rp 101.000 - Rp 150.000/bulan.

Selama pembelajaran daring di masa pandemi Covid-19 sebagian besar mahasiswa IAIN Pekalongan merasa sedih, dan tidak menginginkan pembelajaran secara online jika pandemi sudah berakhir. Adapun saat new normal ini $48 \%$ mahasiswa IAIN Pekalongan menginginkan $100 \%$ konvensional (tatap muka), 45\% mahasiswa IAIN Pekalongan menginginkan 50\% online - 50\% konvensional (tatap muka), dan 7\% mahasiswa IAIN Pekalongan menginginkan 100\% online.

\section{Kesimpulan}

Pelaksanaan pembelajaran daring yang diterapkan di IAIN Pekalongan memungkinkan mahasiswa untuk mengikuti perkuliahan dari rumah masing-masing, sehingga mendorong munculnya perilaku social distancing dan physical distancing guna meminimalisir kerumunan mahasiswa di kampus agar pencegahan Covid-19 semakin optimal selain protokol kesehatan yang diwajibkan saat memasuki area kampus. Pembelajaran daring memberikan kemudahan dalam memberikan transfer informasi pada berbagai situasi dan kondisi.

Media e-learning yang digunakan oleh mahasiswa IAIN Pekalongan selama pandemi Covid-19 adalah google classroom, e-learning milik kampus, dan whatsapp. Untuk perkulaihan tatap muka secara online menggunakan zoom dan google meet. Durasi penggunaan waktu untuk pembelajaran daring selama pandemi Covid-19 antara 5-6 jam/hari atau setara dengan tatap muka konvensional, ini dapat diartikan bahwa dosen-dosen IAIN Pekalongan melakukan tugas sebagaimana mestinya meskipun dari rumah (work from home). Adapun penyedia jasa internet yang digunakan adalah Indosat, XL, Three, dan Smartfren dengan kuota data internet yang dihabiskan antara 6-10 GB/bulan dan 16-20 GB/bulan.

Selain manfaat pembelajaran daring tersebut, terdapat perasaaan mahasiswa-mahasiswa khususnya IAIN Pekalongan yaitu merasa sedih dengan diberlakukannya pembelajaran daring karena beberapa hal antara lain : 1) kurangnya intensitas tatap muka secara langsung dengan dosen dan sesama mahasiswa, 2) faktor sinyal internet dan kuota, 3) banyaknya tugas dari dosen. Pihak sudah mengeluarkan kebijakan dengan adanya subsidi kuota dan kerjasamanya 
dengan operator penyedia jasa internet dengan harapan masalah-masalah yang dihadapi mahasiswa bisa teratasi.

\section{Referensi}

Almarzooq, Z. I., Lopes, M., \& Kochar, A. (2020). Virtual Learning During the COVID-19 Pandemic: A Disruptive Technology in Graduate Medical Education. Journal of the American College of Cardiology, 75(20), 2635-2638. https://doi.org/10.1016/j.jacc.2020.04.015

Chiodini, J. (2020). Online learning in the time of COVID-19. Travel Medicine and Infectious Disease, 34(April), 101669. https://doi.org/10.1016/j.tmaid.2020.101669

Firman, F., \& Rahayu, S. (2020). Pembelajaran Online di Tengah Pandemi Covid-19. Indonesian Journal of Educational Science (IJES), 2(2), 81-89. https://doi.org/10.31605/ijes.v2i2.659

Goldschmidt, K. (2020). The COVID-19 Pandemic: Technology use to Support the Wellbeing of Children. Journal of Pediatric Nursing, 53, 88-90. https://doi.org/10.1016/j.pedn.2020.04.013

Goulas, S., \& Megalokonomou, R. (2020). School attendance during a pandemic. Economics Letters, 193, 109275. https://doi.org/10.1016/j.econlet.2020.109275

Guessoum, S. B., Lachal, J., Radjack, R., Carretier, E., Minassian, S., Benoit, L., \& Moro, M. R. (2020). Adolescent psychiatric disorders during the COVID-19 pandemic and $\begin{array}{llll}\text { lockdown. Psychiatry } & \text { Research, } & 2913264 .\end{array}$ https://doi.org/10.1016/j.psychres.2020.113264

Herliandry, L. D., Nurhasanah, Suban, M. E., \& Heru, K. (2020). Pandemic learning during the Covid-19. Jurnal Teknologi Pendidikan, 22(1), 65-70. https://doi.org/https://doi.org/10. 21009/jtp.v22i1.15286

Kapasia, N., Paul, P., Roy, A., Saha, J., Zaveri, A., Mallick, R., Barman, B., Das, P., \& Chouhan, P. (2020). Impact of lockdown on learning status of undergraduate and postgraduate students during COVID-19 pandemic in West Bengal, India. Children and Youth Services Review, 116, 105194. https://doi.org/10.1016/j.childyouth.2020.105194

Makarim, N. A. (n.d.). Surat Edaran Nomor 3 Tahun 2020 Tentang Pencegahan Corona Virus Disase (Covid-19) pada Satuan Pendidikan.

Marshall, C. S., Yamada, S., \& Inada, M. K. (2008). Using problem-based learning for pandemic preparedness. Kaohsiung Journal of Medical Sciences, 24(3 SUPPL.), 39-45. https://doi.org/10.1016/S1607-551X(08)70093-7 
Nizam. (2020). Surat Edaran Direktur Jenderal Pendidikan Tinggi Republik Indonesia Nomor 1 Tahun 2020 Pencegahan Penyebaran Corona Virus Disease (Covid-19) di Perguruan Tinggi, Kementerian Pendidikan dan Kebudayaan.

Ransing, R., Adiukwu, F., Pereira-Sanchez, V., Ramalho, R., Orsolini, L., Teixeira, A. L. S., Gonzalez-Diaz, J. M., da Costa, M. P., Soler-Vidal, J., Bytyçi, D. G., El Hayek, S., Larnaout, A., Shalbafan, M., Syarif, Z., Nofal, M., \& Kundadak, G. K. (2020). Mental Health Interventions during the COVID-19 Pandemic: A Conceptual Framework by Early Career Psychiatrists. Asian Journal of Psychiatry, 51(April), 102085. https://doi.org/10.1016/j.ajp.2020.102085

Rinehart, R. (2012). Thinking about Method. Teaching Undergraduate Research in Religious Studies. https://doi.org/10.1093/acprof:oso/9780199732869.003.0004

Setiawan, T., Irlanto Sudomo, R., \& Nur Hasanah, F. (2019). Adaptive Hypermedia System Development Based on Moodle to Overcome the Diversity of Learning Style on Vocational Education in Indonesia. Journal of Physics: Conference Series, 1273(1). https://doi.org/10.1088/1742-6596/1273/1/012005

Singh, R. P., Javaid, M., Kataria, R., Tyagi, M., Haleem, A., \& Suman, R. (2020). Significant applications of virtual reality for COVID-19 pandemic. Diabetes and Metabolic Syndrome: Clinical Research and Reviews, 14(4), 661-664. https://doi.org/10.1016/j.dsx.2020.05.011

Smaldino, S. E., Russell, J. D., Heinich, R., \& Molenda, M. (2004). Instructional Technology and Media for Learning 8th Edition (p. 432). 